\title{
TINGKAT KETANGGAPAN PELAYANAN KESEHATAN RAWAT INAP DI INDONESIA
}

\author{
In-Patient Health Services Responsiveness Level in Indonesia
}

\author{
Lukman Prayitno, Primasari Syam, Hendrianto Trisnowibowo, Mugeni Sugiharto \\ Puslitbang Humaniora dan Manajemen Kesehatan, Kemenkes RI, Jakarta, Indonesia \\ Naskah masuk: 07 Desember 2019 Perbaikan: 14 Juli 2020 Layak terbit: 25 Agustus 2020 \\ https://doi.org/10.22435/hsr.v23i3.2534
}

\begin{abstract}
ABSTRAK
Ketanggapan rawat inap sistem kesehatan berkaitan dengan harapan logis pasien terhadap aspek non medis. Level Ketanggapan dapat secara langsung mempengaruhi kenyamanan pasien. Penelitian bertujuan mengetahui level Ketanggapan rawat inap dan signifikansi karakteristik responden terhadap 8 domain Ketanggapan. Penelitian ini merupakan analisa lanjut data survei Ketanggapan tahun 2017. Metode penelitian adalah cross-sectional dengan pendekatan kuantitatif. Survei ini dilakukan di 34 provinsi di Indonesia. Semua rerata skor Ketanggapan berada pada rentang skor baik. Nilai skor yang paling rendah adalah domain quality basic amenities. Sedangkan nilai skor yang paling tinggi adalah domain confidentiality. Level Ketanggapan rawat inap adalah 8,05 dan masuk kategori baik. Setiap karakteristik mempunyai hubungan signifikan dengan satu atau lebih domain Ketanggapan. Nilai Ketanggapan rawat inap bisa ditingkatkan dengan memperbaiki 3 domain Responsiveness, yaitu Dignity, Access to social network, Choice of provider.
\end{abstract}

Kata Kunci: ketanggapan; rawat inap; delapan domain; aspek non medis

\begin{abstract}
Responsiveness of the health system in in-patient services is closely related to patient's reasonable expectations of nonclinical aspects for inpatient care. A comfortable patient can straight influence level of responsiveness. This study aimed to determine level of in-patient responsiveness and significance of respondent characteristics on eight responsiveness domains. It was a further analysis of the Responsiveness Survey of 2017. A Cross-Sectional design with a quantitative approach and has performed in 34 provinces in Indonesia. Most mean responsiveness scores were in range of good scores. Moreover, Lowest score was quality basic amenities domain, while highest score was confidentiality domain. Level of in-patient responsiveness was good category $(8,05)$. Each characteristic has significantly correlated with one or more responsiveness domains. We can increase in-patient responsiveness value that less than 8,0 through improving three responsiveness domains, i.e., dignity, access to social network, and provider choice.
\end{abstract}

Keywords: Responsiveness, In-patient, Eight Domains, Non-Clinical Aspects

\section{PENDAHULUAN}

Berdasarkan laporan kesehatan tahun 2000 yang dikeluarkan oleh Organisasi Kesehatan Dunia (WHO), kinerja sistem kesehatan dievaluasi berdasarkan tiga tujuan utama : meningkatkan kesehatan, pembiayaan yang adil dan daya tanggap. Responsiveness (ketanggapan) sistem kesehatan berkaitan dengan harapan pasien yang layak atau pantas dari aspek perawatan kesehatan non-medis (Karami-Tanha et al., 2014); cara dan lingkungan dimana pasien diperlakukan selama interaksi mereka dengan sistem kesehatan (Valentine,Verdes-Tennant and Bonsel, 2015). Harapan yang layak adalah prinsip, hukum dan standar perawatan non-medis yang dikenal dan diterima (De Silva, 2000).

Korespondensi:

Lukman Prayitno

Puslitbang Humaniora dan Manajemen Kesehatan, Kemenkes RI, Jakarta, Indonesia

E-mail: yohaneslukman@gmail.com 
Model responsiveness terdiri dari 8 unsur aspek non-medis dari perawatan kesehatan. Delapan unsur ini dikelompokkan dalam 2 komponen penting yaitu 1. penghargaan (respect) pada pasien dan 2. orientasi pada pasien (Murray and Frenk, 2000). Komponen penghargaan (respect) pada pasien terdiri dari menjaga martabat pasien, membangun komunikasi yang jelas, menjaga kerahasiaan informasi pasien dan otonomi individu dan keluarga untuk membuat keputusan tentang kesehatan mereka sendiri. Komponen orientasi pada pasien terdiri dari perhatian cepat, akses jaringan sosial selama perawatan, kualitas fasilitas dasar dan pilihan penyedia perawatan (Murray and Frenk, 2000).

Bagi pasien, responsiveness sistem kesehatan merupakan komponen penting dari keseluruhan pengalaman mereka saat menjalani perawatan medis. Pasien memahami dan menilai berbagai aspek pengalaman mereka sepanjang waktu mereka di fasilitas perawatan kesehatan (Adesanya et al., 2012). Harapan pasien (medis atau non-medis), sebagai salah satu faktor psikologis penting, dianggap mempengaruhi evaluasi perawatan dan kepuasan mereka dengan hasil perawatan (Yao et al., 2016) (Prudêncio et al., 2013).

Berdasarkan data Riset Kesehatan Dasar (Riskesdas) tahun 2007. Terdapat delapan (8) domain yang dikumpulkan dalam Riskesdas 2007 dengan persentase yaitu kecepatan pemberian pelayanan $(84,8 \%)$, dilayani dengan sopan dan ramah $(87,0 \%)$, komunikasi (85,4\%), ikut mengambil keputusan $(84,8 \%)$, kerahasiaan $(86,1 \%)$, kebebasan memilih sarana $(84,5 \%)$, kebersihan lingkungan $(82,9 \%)$ dan akses keluarga dan sosil (87,5\%) (Riskesdas 2007, 2008).

Pada era Jaminan Kesehatan Nasional, telah terjadi peningkatan akses pelayanan kesehatan yang berdampak terhadap peningkatan kunjungan pasien di fasilitas kesehatan, termasuk di rumah sakit. Hal ini menyebabkan pelayanan kurang optimal, ditunjukkan dengan ketidakpuasan pasien di era Jaminan Kesehatan Nasional (Trisnawati K. Sumarni. Fudholi A., 2015).

Meningkatnya nilai responsiveness pasien dapat secara langsung mempengaruhi kenyamanan pasien. Berdasarkan hal tersebut, maka artikel ini menganalisa data penelitian "Survey Responsiveness dalam Sistem Pelayanan Kesehatan di Indonesia Tahun 2017". Adapun tujuan analisa data ini adalah mengetahui level responsiveness rawat inap dan signifikansi hubungan karakteristik responden terhadap domain responsiveness.

\section{METODE}

Penelitian responsiveness rawat inap merupakan analisa lanjut secara kuantitatif data survey responsiveness tahun 2017. Survei responsiveness merupakan studi cross-sectional deskriptif dengan pendekatan kuantitatif. Survei ini dilakukan di 34 provinsi di Indonesia yang tersebar di 10.370 rumah tangga terpilih yang tersebar di 610 desa, di 207 kecamatan. Penelitian dilaksanakan pada tahun 2017 dengan lama pengumpulan data adalah 1 bulan. Pengumpulan data dilakukan di komunitas (community based). Survei ini menggambarkan masalah ketanggapan masyarakat terhadap pelayanan rawat inap di fasilitas kesehatan di seluruh pelosok Indonesia. Instrumen responsiveness layanan kesehatan menggunakan kuesioner Studi Survei Multi-Negara, yang dikembangkan dan divalidasi oleh WHO. Instrumen tersebut disesuaikan dengan kondisi masyarakat dan layanan kesehatan di Indonesia. Health system responsiveness rawat inap dibagi menjadi dua konsep yaitu: respek terhadap pelanggan dan orientasi pada pelanggan. Konsep respek terhadap pelanggan terdiri dari 4 domain yaitu: Dignity (DIG : dilayani dengan penuh hormat dan sopan); Autonomy (AUT : keterlibatan dalam perawatan dan pengobatan), Confidentiality $(\mathrm{Cl}$ : kerahasiaan komunikasi pasien), Communication (COM : komunikasi dengan petugas kesehatan). Konsep orientasi pelanggan terdiri dari 4 domain yaitu: Prompt of Attention (PA: kecepatan memperoleh pelayanan), Quality basic amenities (ENV : kondisi lingkungan pelayanan), Access to sosial network (SS : akses kepada support keluarga dan sosial), Choice of provider $(\mathrm{CH}$ : dapat memilih pemberi pelayanan kesehatan). Semua pertanyaan kesimpulan di kuesioner di semua domain responsiveness yang akan dimasukkan dalam perhitungan rumus responsiveness. Adapun uraian cara mengukur level ketanggapan tersebut adalah sebagai berikut:

\section{Rumus Untuk Menghitung Level Ketanggapan (Responsiveness) pada 8 (delapan) domain}

Berdasarkan Valentine, dkk dalam bukunya "Estimating Responsiveness Level and Distribution for 191 Countries: Methods and Results in GPE Discussion Paper Series: No. 22" yang diterbitkan di Geneva oleh World Health Organization, rumus untuk menghitung level ketanggapan adalah (Nicole BV. Amala de Silva. Christopher JL Murray, 2000). 


$$
\operatorname{Re} s p=\sum_{i=1}^{n} W_{i} S_{i}
$$

Level responsiveness setiap responden yang pernah mendapat pelayanan rawat inap pada 1 tahun terakhir diperoleh dengan menjumlahkan hasil perkalian dari skor (S) dengan bobot koefisien (W) masing-masing domain responsiveness. Bobot koefisien untuk setiap domain responsiveness yaitu: DIG $(0,125)$, COM $(0,125)$, AUT $(0,125), \mathrm{Cl}(0,125)$, PA $(0,20)$, ENV $(0,15)$, SS $(0,10)$ dan $\mathrm{CH}(0,05)$.

Skor responsiveness dihitung dengan formula sebagai berikut :

$$
s=\sum X_{i} * N_{i} / N
$$

$\begin{aligned} \mathrm{S}= & \text { Rerata skor responsiveness setiap elemen } \\ \mathrm{Xi}= & \text { Skor item responsiveness yang terkandung dalam setiap } \\ & \text { elemen }\end{aligned}$

$$
\begin{array}{ll}
\mathrm{Ni} & =\text { Jumlah responden yang memperoleh skor sama } \\
\mathrm{N} & =\text { Total responden }
\end{array}
$$

Rerata skor (S) responsiveness setiap domain diperoleh dari penjumlahan semua nilai jawaban pertanyaan kesimpulan di setiap domain dibagi dengan total responden. Rerata skor responsiveness juga bisa diperoleh dari jumlah responden dengan skor yang sama dikalikan dengan skor item jawaban pertanyaan setiap domain responsiveness dalam setiap elemen dibagi dengan jumlah responden yang memperoleh skor yang sama. Klasifikasi level responsiveness adalah skor 2,0 - 2,9 = sangat buruk; skor 3,0-4,0 = buruk; skor 5,0 - 6,9 = sedang; skor $7,0-8,9$ = baik; skor $9,0-10,0=$ sangat baik,

Berdasarkan keterangan tersebut, maka variable dependent (terikat) dalam penelitian ini adalah 8 domain responsiveness. Delapan domain ini terdiri dari DIG, AUT, CI, COM, PA, ENV, SS, CH.

\begin{tabular}{|c|c|c|c|}
\hline No & Karakteristik Responden & Jumlah & Persentase \\
\hline \multirow[t]{3}{*}{1} & Jenis Kelamin & & \\
\hline & a. Laki & 272 & 34,04 \\
\hline & b. Perempuan & 527 & 65,96 \\
\hline \multirow[t]{5}{*}{2} & Kelompok umur & & \\
\hline & a. $18-29$ tahun & 170 & 21,28 \\
\hline & b. $30-44$ tahun & 314 & 39,30 \\
\hline & c. $45-59$ tahun & 196 & 24,53 \\
\hline & d. $\geq 60$ tahun & 119 & 14,89 \\
\hline \multirow[t]{4}{*}{3} & Tingkat Pendidikan & & \\
\hline & a. Rendah (Tidak Sekolah s/d tidak tamat SD & 292 & 36,55 \\
\hline & b. Sedang (Tamat SD s/d tamat SLTA) & 418 & 52,32 \\
\hline & c. Tinggi (D1 s/d Perguruan Tinggi) & 89 & 11,14 \\
\hline \multirow[t]{6}{*}{4} & Pengeluaran & & \\
\hline & a. Kuintil 1 (Rp. $50.000-740.000)$ & 50 & 6,26 \\
\hline & b. Kuintil 2 (Rp. $741.500-1.190 .633)$ & 71 & 8,89 \\
\hline & c. Kuintil 3 (Rp. 1.192.000 - 1.700.000) & 124 & 15,52 \\
\hline & d. Kuintil 4 (Rp. $1.703 .000-2.500 .000)$ & 162 & 20,28 \\
\hline & e. Kuintil 5 (Rp. $2.502 .500-3.100 .000)$ & 392 & 49,06 \\
\hline \multirow[t]{4}{*}{5} & Kepemilikan Asuransi & & \\
\hline & a. $\mathrm{PBI}$ (Penerima Bantuan luran) & 314 & 39,30 \\
\hline & b. Non PBI & 227 & 28,41 \\
\hline & c. Tidak punya asuransi & 258 & 32,29 \\
\hline \multirow[t]{3}{*}{6} & Klasifikasi tempat tinggal & & \\
\hline & a. Perkotaan & 639 & 79,97 \\
\hline & b. Perdesaan & 160 & 20,03 \\
\hline
\end{tabular}
Sedangkan variabel independent (bebas) dalam penelitian ini adalah jenis kelamin, umur, tingkat

Tabel 1. Karakteristik Responden Responsiveness Rawat Inap $(n=799)$

Sumber : Penelitian Responsiveness Tahun 2017 
pendidikan, pengeluaran, kepemilikan asuransi, wilayah tempat tinggal. Analisis untuk memperoleh nilai signifikan ( $p$-value) variable independen dengan dependen dilakukan dengan menggunakan uji chisquare, karena data berdistribusi tidak normal.

\section{HASIL}

Target responden dalam penelitian ini adalah 10.370 ruta, namun ada sejumlah 10.004 ruta yang berhasil dikunjungi, terdapat 9.947 orang yang terpilih menjadi responden penelitian (eligible person) yang berhasil diwawancara. Sebanyak 4.652 (46,77\%) yang pernah mendapatkan pelayanan kesehatan di fasilitas kesehatan yaitu 4.191 (90 \%) di rawat jalan, 278 (6 \%) di kunjungan rumah dan 799 (17,2\%) di rawat inap.

Berdasarkan tabel 1, mayoritas responden adalah perempuan. Mayoritas responden berada pada kelompok umur 30 - 44 tahun. Mayoritas responden berada pada kelompok tingkat pendidikan sedang yaitu tamat SD sampai dengan SLTA. Mayoritas pengeluaran responden adalah Rp. 2.502.500-3.100.000. Mayoritas responden

Tabel 2. Tanggapan Responden terhadap 8 Domain Responsiveness Rawat Inap $(\mathrm{n}=799)$

\begin{tabular}{llccccc}
\hline & & \multicolumn{5}{c}{ Tanggapan Responden } \\
\cline { 3 - 7 } No Domain & $\begin{array}{c}\text { Sangat } \\
\text { Baik }\end{array}$ & Baik & Sedang & Buruk & $\begin{array}{c}\text { Sangat } \\
\text { Buruk }\end{array}$ \\
\hline 1 & PA & 150 & 544 & 93 & 11 & 1 \\
2 & DIG & 202 & 538 & 53 & 6 & - \\
3 & COM & 149 & 569 & 74 & 6 & 1 \\
4 & AUT & 137 & 591 & 66 & 3 & 2 \\
5 & CI & 194 & 546 & 54 & 3 & 2 \\
6 & CH & 164 & 539 & 89 & 6 & 1 \\
7 & ENV & 128 & 562 & 99 & 10 & - \\
8 & SS & 263 & 493 & 42 & 1 & - \\
\hline
\end{tabular}

Sumber: Penelitian Responsiveness Tahun 2017

Tabel 3. Nilai Total Masing-masing Domain Responsiveness $(\mathrm{n}=799)$

\begin{tabular}{clccc}
\hline No & Domain & Rerata Skor Responsiveness & Bobot Responsiveness & $\begin{array}{c}\text { Level Responsiveness }= \\
\text { Rerata } \mathbf{x} \text { Bobot }\end{array}$ \\
\hline 1 & DIG & 7,93 & 0,125 & 0,99 \\
2 & COM & 8,15 & 0,125 & 1,02 \\
3 & AUT & 8,15 & 0,125 & 1,02 \\
4 & CI & 8,32 & 0,125 & 1,04 \\
5 & PA & 8,08 & 0,2 & 1,62 \\
6 & ENV & 7,53 & 0,15 & 1,13 \\
7 & SS & 8,19 & 0,1 & 0,82 \\
8 & CH & 8,15 & 0,05 & 0,41 \\
\hline \multicolumn{7}{r}{ Total } \\
\hline
\end{tabular}

Sumber: Penelitian Responsiveness Tahun 2017

Tabel 4. Korelasi Karakteristik Responden terhadap Domain Responsiveness $(n=799)$

\begin{tabular}{|c|c|c|c|c|c|c|c|}
\hline \multirow[b]{2}{*}{ No } & \multirow[b]{2}{*}{ Domain } & \multicolumn{6}{|c|}{ Nilai Signifikansi Hubungan ( $p$-value) } \\
\hline & & $\begin{array}{l}\text { Jenis } \\
\text { Kelamin }\end{array}$ & $\begin{array}{l}\text { Kelompok } \\
\text { Umur }\end{array}$ & $\begin{array}{c}\text { Tingkat } \\
\text { Pendidikan } \\
\text { (3 Kategori) }\end{array}$ & $\begin{array}{l}\text { Pengeluaran } \\
\text { (5 Kategori) }\end{array}$ & $\begin{array}{c}\text { Kepemilikan } \\
\text { Asuransi } \\
\text { (3 Kategori) }\end{array}$ & $\begin{array}{c}\text { Wilayah (Desa/ } \\
\text { Kelurahan) }\end{array}$ \\
\hline 1 & PA & 0,095 & 0,595 & 0,085 & 0,114 & 0,199 & 0,008 \\
\hline 2 & DIG & 0,262 & 0,996 & 0,329 & 0,093 & 0,186 & 0,586 \\
\hline 3 & COM & 0,137 & 0,57 & 0,026 & 0,433 & 0,016 & 0,279 \\
\hline 4 & AUT & 0,736 & 0,092 & 0,52 & 0,28 & 0,015 & 0,12 \\
\hline 5 & $\mathrm{Cl}$ & 0,343 & 0,022 & 0,279 & 0,026 & 0,029 & 0,002 \\
\hline 6 & $\mathrm{CH}$ & 0,646 & 0,165 & 0,072 & 0,555 & 0,278 & 0,106 \\
\hline 7 & ENV & 0,009 & 0,006 & 0,317 & 0,669 & 0,83 & 0,005 \\
\hline 8 & SS & 0,766 & 0,034 & 0,67 & 0,616 & 0,353 & 0,329 \\
\hline
\end{tabular}

Sumber: Penelitian Responsiveness Tahun 2017 
memiliki asuransi PBI. Mayoritas responden tinggal di perkotaan. Berdasarkan tabel 2, semua domain mayoritas ditanggapi baik oleh responden.

Hasil perhitungan 8 domain dengan menggunakan rumus di bagian metode diperoleh satu nilai responsiveness rawat inap seperti yang ada di tabel 3 .

Semua rerata skor responsiveness berada pada rentang skor baik. Nilai skor yang paling rendah adalah domain ENV (environment). Sedangkan nilai skor yang paling tinggi adalah domain $\mathrm{Cl}$ (confidentiality). Total nilai responsiveness rawat inap adalah 8,05.

Berdasarkan tabel 4 diketahui bahwa setiap karakteristik mempunyai hubungan signifikan dengan satu atau lebih domain responsiveness. Domain ENV secara signifikan dipengaruhi oleh karakteristik jenis kelamin ( $p$-value $=0,009$ ). Karakteristik kelompok umur secara signifikan mempengaruhi domain $\mathrm{Cl}$ ( $p$-value $=0,022)$ dan domain ENV ( $p$-value : 0,006) serta domain SS ( $p$-value : 0,034). Karakteristik tingkat pendidikan secara signifikan mempengaruhi domain COM ( $p$-value $=0,026)$. Karakteristik pengeluaran secara signifikan mempengaruhi domain $\mathrm{Cl}$ ( $p$-value $=0,026)$. Karakteristik kepemilikan asuransi secara signifikan mempengaruhi domain COM ( $p$-value : 0,016$)$, domain AUT ( $p$-value : 0,015), dan domain $\mathrm{Cl}$ ( $p$-value : 0,029). Karakteristik wilayah (desa/ kelurahan) tempat tinggal responden secara signifikan mempengaruhi domain PA ( $p$-value : $0,008)$, domain $\mathrm{Cl}(p$-value $=0,002)$ dan domain ENV $(p$-value $=0,005)$.

\section{PEMBAHASAN}

Berdasarkan guideline survey yang dibuat oleh WHO yang berjudul "The Health Systems Responsiveness Analytical Guidelines for Surveys in the Multi-country Survey Study" tahun 2005, penilaian responsiveness (ketanggapan) terkait dengan harapan pasien terhadap layanan kesehatan yang layak yang diakui sebagai bagian penting dari kinerja sistem kesehatan. Mempromosikan responsiveness (ketanggapan) dapat meningkatkan pemanfaatan sistem kesehatan dengan meningkatkan kepatuhan pasien terhadap rekomendasi medis dan mengarah pada peningkatan kesehatan (Rice, Robone and Smith, 2012).

Pada tabel 3 diketahui bahwa semua rerata skor responsiveness berada pada rentang skor baik. $\mathrm{Hal}$ ini sesuai dengan hasil penelitian sebelumnya yang menyatakan bahwa sebagian besar responden menilai masing-masing domain ini secara positif (OECD, 2015) (Julia Rottger, 2016).

Berdasarkan penelitian yang dilakukan oleh Melo, et al tahun 2017, di antara domain yang diteliti : dignity (DIG), confidentiality (Cl), dan communication (COM) mencapai tingkat ketanggapan yang memadai. Di sisi lain, choice of provider $(\mathrm{CH})$ dan prompt of attention (PA) mendapatkan nilai yang paling jelek. Domain communication (COM) dilaporkan sebagai domain terpenting untuk perawatan berkualitas $(41,2 \%)$, diikuti oleh dignity $(39,2 \%)$, dan prompt of attention $(11,5 \%)$. Perlu dicatat bahwa domain Choice of provider $(\mathrm{CH})$ dan Prompt of Attention (PA) adalah domain yang menerima penilaian terburuk (Melo et al., 2017).

Dengan lebih memperhatikan hak-hak pasien, maka memberi pasien kesempatan untuk memilih layanan perawatan kesehatan $(\mathrm{CH})$, menyediakan akses cepat ke perawatan darurat dan mempertimbangkan autonomy (AUT) adalah aspek terpenting dalam responsiveness kesehatan. Menurut pandangan pasien, prompt attention (PA) dilaporkan sebagai aspek terpenting dalam responsiveness. Prompt Attention (PA) dan dignity (DIG) memiliki peringkat tinggi dari pandangan pasien. Sebagian besar subkelompok pasien, confidentiality $(\mathrm{Cl})$ memiliki tingkat yang lebih rendah. Dalam penelitian yang dilakukan oleh Karami, dkk, confidentiality (CI) dan dignity (DIG) memiliki kinerja terbaik dalam sistem perawatan rawat inap. Hal ini menunjukkan bahwa sistem kesehatan memiliki kinerja yang dapat diterima dalam lingkup ini. Ini berarti bahwa sistem itu hampir responsiveness terhadap privasi di lingkungan dan catatan medis serta kemampuan untuk memberikan perhatian penuh hormat. Autonomiy (AUT) dan choice of provider $(\mathrm{CH})$ menerima kinerja terburuk dalam layanan rawat inap. Autonomiy (AUT) adalah salah satu prinsip etika biomedis yang didefinisikan sebagai rasa hormat pada pasien dan pilihan informasinya (Karami-Tanha et al., 2014).

Berdasarkan tabel 4, karakteristik wilayah responden secara signifikan mempengaruhi jawaban domain prompt of attention (PA). Hal ini sesuai dengan penelitian Diógenes et al. tahun 2009 yang menyatakan bahwa setiap pasien memiliki kebutuhan dan harapan yang berbeda-beda. Oleh karena itu perlu menyatakan parameter lain misalnya kelompok usia dalam studi evaluasi layanan (Diogenes, 2009).

Berdasarkan tabel 4, karakteristik pendidikan responden tidak mempunyai hubungan signifikan terhadap domain prompt of attention (PA). Hal ini 
sesuai dengan penelitian yang dilakukan Melo, dkk yang menyatakan penelitian ini tidak menemukan hubungan yang signifikan antara tingkat pendidikan dan domain PA ( $p=0,191$ ) (Melo et al., 2017). Penelitian lain yang dilakukan Lovision, dkk telah menemukan bahwa pada orang dewasa yang lebih tua yang tidak memiliki pendidikan mendapatkan waktu yang lebih lama untuk penjadwalan janji. Hasil yang diamati dalam penelitian ini mungkin dipengaruhi oleh rendahnya tingkat pendidikan yang lazim di kalangan pengguna lembaga yang dinilai (Louvision, et al., 2008)

Berdasarkan literature, ketidakpuasan pengguna layanan publik adalah terkait dengan waktu tunggu. Oleh karena itu perlu mengembangkan strategi untuk menyediakan perawatan kesehatan yang lebih cepat dan lebih efektif (Santiago, et al., 2013). Sehubungan dengan domain prompt of attention (PA), WHO menemukan bahwa domain ini dianggap paling penting oleh pengguna layanan kesehatan. Dalam studi ini, domain ini penting sehingga ditempatkan pada urutan tertinggi ketiga. Namun, nilainya adalah yang terburuk di antara domain yang lainnya. Berdasarkan guideline survey yang dibuat oleh WHO yang berjudul "The Health Systems Responsiveness Analytical Guidelines for Surveys in the Multi-country Survey Study" tahun 2005, menyatakan bahwa orang miskin cenderung menyebutkan responsiveness layanan kesehatan yang lebih buruk terhadap domain PA, DIG, COM, AUT (Rice, Robone and Smith, 2012).

Mempertimbangkan aspek-aspek tersebut diatas, jaringan kesehatan terpadu bertujuan untuk mengintegrasikan layanan kesehatan sehingga bisa memberikan perawatan yang efektif dan konsisten dalam kaitannya dengan kebutuhan pasien. Studi telah menunjukkan bahwa layanan pada jaringan kesehatan terpadu dapat meningkatkan kualitas klinis, hasil kesehatan, dan kepuasan pengguna, di samping mengurangi waktu tunggu untuk layanan dan biaya sistem perawatan kesehatan (Silva, 2011).

Karakteristik pengeluaran responden tidak mempunyai hubungan terhadap domain dignity (DIG). Penelitian lain menyatakan domain DIG berkorelasi dengan ras (Melo et al., 2017), (Souza et al., 2012) dan usia (Lenardt et al., 2007). Kepatuhan dan keberhasilan setiap rekomendasi terapi berkorelasi dengan kepercayaan pasien dan rasa hormat terhadap keinginan pasien (Taddeo, et al., 2012). Dengan demikian, profesional kesehatan harus memberikan perawatan yang hormat kepada orang dewasa yang lebih tua terlepas dari karakteristik pasien. Penting untuk dicatat bahwa komunikasi dengan pasien memiliki fungsi terapeutik dan merupakan bagian penting dalam proses perawatan (Lenardt et al., 2007).

Karakteristik tingkat pendidikan dan kepemilikan asuransi responden secara signifikan mempengaruhi domain communication (COM). Penelitian lain menyatakan orang dewasa yang lebih tua yang diwawancarai dalam penelitian ini berpendapat bahwa para profesional melakukan dialog, memberikan penjelasan yang memadai dan jelas mengenai kesehatan dan/ atau situasi perawatan. Ini mendukung hubungan pasien dan pemberi layanan kesehatan binomial, mengoptimalkan proses perawatan, karena para profesional memberikan pengetahuan yang lebih baik tentang masalahmasalah kesehatan pasien, serta prioritas masingmasing kasus (Gromulska et al., 2014) (Lima et al., 2014).

Karakteristik kelompok umur secara signifikan mempengaruhi domain autonomy (AUT). Penelitian lain juga menyatakan orang dewasa yang lebih tua tanpa pendidikan memiliki lebih sedikit kesempatan untuk ikut memutuskan perawatannya. (Melo et al., 2017). Penelitian lain menyatakan korelasi domain AUT dengan pendidikan yaitu kualitas pelayanan kesehatan yang diterima oleh orang dewasa yang kurang berpendidikan lebih rendah jika dibandingkan dengan mereka yang memiliki tingkat pendidikan yang lebih tinggi. Hal ini menghasilkan ketidaksetaraan sosial mengenai penyediaan layanan kesehatan (Noronha \& Andrade, 2005).

Domain $\mathrm{Cl}$ (kerahasiaan) adalah persyaratan penting perilaku profesional kesehatan dan dianggap sebagai hak pasien, serta tanggung jawab etis penyedia layanan (Sampaio \& Rodrigues, 2014). Hasil penelitian Lima, dkk menunjukkan bahwa para profesional kesehatan di unit penelitian bekerja dengan memberikan perawatan manusiawi pada orang dewasa yang lebih tua agar terjadi komunikasi yang tepat dan kerahasiaan informasi pribadi yang terjaga sesuai dalam perjanjian. Lima, dkk menilai berbagai layanan kesehatan masyarakat, telah mencatat bahwa sebagian besar pengguna yakin pada penyedia layanan dalam menjaga kerahasiaan informasi pribadi mereka (Lima et al., 2014).

Berdasarkan berdasarkan guideline survey yang dibuat oleh WHO yang berjudul "The Health Systems Responsiveness Analytical Guidelines for Surveys in the Multi-country Survey Study" tahun 2005 , domain choice of provider $(\mathrm{CH})$ berkorelasi 
lemah dengan tingkat pendidikan. Dalam guideline ini menyatakan bahwa terdapat hubungan domain $\mathrm{CH}$ dengan orang miskin. Pernyataan WHO ini bisa diartikan bahwa orang miskin cenderung mempunyai pendidikan yang kurang. Penelitian ini mengatakan domain $\mathrm{CH}$ berkaitan dengan usia karena domain $\mathrm{CH}$ mendapat penilaian terburuk dari orang dewasa yang lebih tua (24,4\%) (Rice, Robone and Smith, 2012). Hal ini disebabkan oleh berkurangnya kemungkinan mereka memilih penyedia layanan di unit kesehatan masyarakat ( Andrade, et al., 2010).

Penelitian ini menyatakan bahwa karakteristik jenis kelamin, kelompok umur, dan wilayah tempat tinggal responden secara signifikan mempengaruhi domain Quality basic amenities (ENV). Penelitian lain menyatakan domain ENV mempunyai nilai lebih tinggi dari perspektif perempuan, kuintil pendapatan yang lebih tinggi, pasien dengan pendidikan diatas 12 tahun, pasien dengan umur dibawah 60 tahun dan pasien dengan lama sakit kurang dari 10 tahun dibanding sub kelompok lainnya (Karami-Tanha et al., 2014). Penelitian lain menyatakan bahwa terkecuali kebersihan ruang tunggu, aspek-aspek lain yang terkait dengan fasilitas fisik dinilai tidak memadai oleh hampir setengah dari orang dewasa yang diwawancarai. Keluhan pengguna berulang dalam literatur tentang buruknya kondisi infrastruktur dan kebersihan layanan kesehatan masyarakat (Medeiros et al., 2010). Peningkatan aspek-aspek ini tidak tergantung pada investasi besar dalam sumber daya keuangan dan teknologi. Situasi ini mengacu pada konteks manajemen dan budaya organisasi di mana pengguna dipandang sebagai pelanggan berpenghasilan rendah yang dilayani oleh sistem kesehatan masyarakat dan tanpa prioritas, dengan merusak ruang yang didominasi oleh pelanggan berpenghasilan tinggi (Hollanda et al., 2012).

Penelitian ini menyatakan bahwa karakteristik umur pasien rawat inap secara signifikan mempengaruhi domain Access to sosial network (SS). Penelitian lain menyatakan bahwa domain SS lebih penting pada sub kelompok laki-laki, pasien diatas 60 tahun, pasien dengan penghasilan yang lebih rendah dan pasien dengan pendidikan kurang dari 12 tahun (Karami-Tanha et al., 2014).

\section{KESIMPULAN DAN SARAN}

\section{Kesimpulan}

Penelitian responsiveness rawat inap bertujuan untuk mengetahui performa sistem kesehatan rawat inap di Indonesia. Nilai rerata skor responsiveness 4 domain yang berkaitan dengan respek terhadap pasien rawat inap yaitu: dignity $(7,93)$, communication $(8,15)$, autonomy $(8,15)$, confidentiality $(8,32)$. Nilai rerata skor responsiveness 4 domain yang berkaitan dengan orientasi pelanggan. Nilai rerata skor responsiveness 4 domain yang berkaitan dengan orientasi pasien rawat inap yaitu prompt of Attention $(8,08)$, quality basic amenities $(7,53)$, access to sosial network $(8,19)$, choice of provider $(8,15)$. Level responsiveness pelayanan kesehatan rawat inap di Indonesia tahun 2017 adalah 8,05. Nilai level responsiveness ini masuk dalam klasifikasi baik.

Karakteristik jenis kelamin secara signifikan mempengaruhi domain ENV. Karakteristik kelompok umur secara signifikan mempengaruhi domain $\mathrm{Cl}$, ENV, SS. Karakteristik tingkat pendidikan secara signifikan mempengaruhi domain COM. Karakteristik pengeluaran secara signifikan mempengaruhi domain $\mathrm{Cl}$. Karakteristik kepemilikan asuransi secara signifikan mempengaruhi domain COM, domain AUT, dan domain Cl. Karakteristik wilayah (desa/ kelurahan) secara signifikan mempengaruhi domain $\mathrm{PA}$, domain $\mathrm{Cl}$, dan domain ENV.

\section{Saran}

Nilai level responsiveness ini perlu dipertahankan dan bisa ditingkatkan dengan mempertahankan nilai rerata skor responsiveness domain yang sudah mempunyai nilai diatas 8 dan meningkatkan domain yang masih mempunyai nilai rerata skor responsiveness di bawah 8. Meningkatkan domain dignity dengan melayani pasien lebih sopan dan ramah dan menjaga privasi/ keleluasaan pribadi pada saat memeriksa pasien. Meningkatkan domain quality basic amenities dengan menjaga kebersihan ruang rawat inap, menjaga kualitas makanan yang diberikan kepada pasien, memberikan obat yang berkualitas dengan jumlah yang sesuai dengan resep. Meningkatkan domain dignity dan domain quality basic amenities dengan memberikan pelayanan optimal kepada semua pasien dengan tidak membedakan karakteristik pasien.

\section{UCAPAN TERIMA KASIH}

Ucapan terima kasih disampaikan kepada Bapak Sugianto, SKM., M.Sc.PH selaku Kepala Puslitbang Humaniora dan Manajemen Kesehatan dan peneliti yang terlibat dalam kajian ini. 


\section{DAFTAR PUSTAKA}

Adesanya, T., Gbolahan, O., Ghannam, O., Miraldo, M., Patel, B., Verma, R. and Wong, H. (2012), "Exploring the responsiveness of public and private hospitals in Lagos, Nigeria", Journal of Public Health Research, Vol. 1 No. 2, pp. 2-7, doi: 10.4081/jphr.2012.e2

Andrade GRB, Vaitsman J, Farias LO. Metodologia de elaboração do Índice de Responsividade do Serviço (IRS). Cad Saude Publica. 2010;16(3):523-34. https:// doi.org/10.1590/S0102-311X2010000300010.

Desilva, A. and Valentine, N. (2000), "A framework for measuring responsiveness", GPE Discussion Paper Series No. 32, World Health Organization, Geneva.

Diógenes TPM, Mendonça KMPP, Guerra RO. Dimensions of satisfaction of older adult Brazilian outpatients with physical therapy. Rev Bras Fisioter. 2009;13(4):301-7. https://doi.org/10.1590/S141335552009005000038.

Gromulska L, Supranowicz P, Wysoxki MJ, Responsiveness to the hospital patient needs in Poland. Rocz Panstw Zakl Hig. 2014;65(2):155-64.

Hollanda E, Siqueira SAV, Andrade GRB, Molinaro A, Vaistman J. Satisfação e responsividade em serviços de atenção à saúde da Fundação Oswaldo Cruz. Cienc Saude Coletiva. 2012;17(12):3343-52. https:// doi.org/10.1590/S1413-81232012001200019.

Karami-Tanha, F. and Fallah-Abadi, H. (2014), "Health system responsiveness for care of patients with heart failure: evidence form a university hospital", Archives of Iranian Medicine, Vol. 17 No. 11, pp. 736-740. doi: 0141711/AIM.003.

Lenardt MH, Hammerschmidt KSA, Pívaro ABR, Borghi ACS. Os idosos e os constrangimentos nos eventos da internação cirúrgica. Texto Contexto Enferm. 2007;16(4):737-45. https://doi.org/10.1590/S010407072007000400019.

Lima TJV, Arcieri RM, Garbin CAS, Moimaz SAS, Saliba O. Humanização na atenção básica de saúde na percepção de idosos. Saude Soc. 2014:23(1):265-76. https://doi.org/10.1590/S010412902014000100021.

Louvison MCP, Lebrão ML, Duarte YAO, Santos JLF, Malik AM, Almeida ES. Desigualdades no uso e acesso aos serviços de saúde entre idosos do município de São Paulo. Rev Saude Publica. 2008;42(4):733-40. https:// doi.org/10.1590/S0034-89102008000400021.

Medeiros FA, Araújo-Souza GC, Albuquerque-Batista AA, Clara-Costa IC. Acolhimento em uma Unidade Básica de Saúde: a satisfação do usuário em foco. Rev Salud Publica. 2010;12(3):402-13. https://doi.org/10.1590/ S0124-00642010000300006.

Melo, D.D.Silva., René Duarte Martins, R.Duarte., Jesus, R.P.F.Soares., Samico, I.C., Santo, A.C.G.d.E., Assessment of the responsiveness of a public health service from the perspective of older adults, Rev
Saude Publica. 2017;51:62. doi: 10.1590/S15188787.2017051006854.

Murray, C.J. and Frenk, J. (2000), "A framework for assessing the performance of health systems", Bulletin of the World Health Organization, Vol. 78 No. 6, pp. 717-731.

Noronha KVMS, Andrade MV. Desigualdades sociais em saúde e na utilização dos serviços de saúde entre os idosos na América Latina. Rev Panam Salud Publica. 2005;17(5-6):410-8. https://doi.org/10.1590/S102049892005000500013.

Organisation for Economic Co-operation and Development (OECD), Patient Experience With Ambulatory Care, in: Health at a Glance 2015: OECD Indicators, OECD Publishing, Paris, 2015.

Prudêncio, P.S., Mamede, F.V., Dantas, R.A.S., de Souza, L. and Mamede, M.V. (2013), "Adaptation and validation of the patient expectations and satisfaction with prenatal care instrument among Brazilian pregnant women", Revista Latino-Americana de Enfermagem, Vol. 21 No. 3, pp. 704-710. doi: 10.1590/S010411692013000300008.

Report Riskesdas 2007, Badan Litbang Kesehatan, Kementerian Kesehatan. 2008. Jakarta

Rice N, Robone S, Smith P, Vignettes and health systems responsiveness in cross-country comparative analyses. J R Statist Soc A. 2012; 175(1): 1 - 21. DOI: $10.2307 / 23251241$

Röttger, Julia., Busse, Reinhard., How do chronically ill patients rate medical care by their GPs and Specialists? Results of a Germany-wide Survey, Gesundheitswesen 78 (2016) 89-96. DOI: 10.1055/s0041-110669

Sampaio SS, Rodrigues FW. Ética e sigilo profissional. Serv Soc Soc. 2014;117:84-93. https://doi.org/10.1590/ S0101-66282014000100006.

Santiago RF, Mendes ACG, Miranda GMD, Duarte PO, Furtado BMASM, Souza WV. Qualidade do atendimento nas Unidades de Saúde da Família no município de Recife: a percepção dos usuários. Cienc Saude Coletiva. 2013;18(1):35-44. https://doi. org/10.1590/S1413-81232013000100005.

Silva SF. Organização de redes regionalizadas e integradas de atenção à saúde: desafios do Sistema Único de Saúde (Brasil). Cienc Saude Coletiva. 2011;16(6):2753-62. https://doi.org/10.1590/S141381232011000600014.

Souza EHA, Oliveira PAP, Paegle AC, Goes PSA. Raça e o uso dos serviços de saúde bucal por idosos. Cienc Saude Coletiva. 2012;17(8):2063-70. https://doi. org/10.1590/S1413-81232012000800017.

Taddeo OS, Lopes Gomes KWL, Caprara A, Gomes AMA, Oliveira GC, Moreira TMM. Acesso, prática educativa e empoderamento de pacientes com doenças crônicas. Cienc Saude Coletiva. 2012;17(11):2923-30. https:// dx.doi.org/10.1590/S1413-81232012001100009. 
Trisnawati K, Sumarni, Fudholi A. Analisis kepuasan pasien rawat jalan PNS pada masa pelaksanaan ASKES dan JKN. Jurnal Manajemen dan Pelayanan Farmasi. 2015; 5(1):33-9.

Valentine, N., Verdes-Tennant, E. and Bonsel, G. (2015), "Health systems responsiveness and reporting behaviour: multilevel analysis of the influence of individual-level factors in 64 countries", Social Science \& Medicine, Vol. 138, August, pp. 152-160. doi: 10.1016/j.socscimed.2015.04.022.
Valentine, Nicole B., Amala de Silva and Christpher J.L. Murray. 2000. Estimating Responsiveness Level and Distribution for 191 Countries: Methods and Results in GPE Discussion Paper Series: No. 22. Geneva: World Health Organization.

Yao, J., Li, D.D., Yang, Y.Q., McGrath, C.P.J. and Mattheos, N. (2016), "What are patients' expectations of orthodontic treatment: a systematic review", BMC Oral Health, Vol. 16 No. 19, DOI 10.1186/s12903016-0182-3 